\title{
Development of PCR assays to detect iridovirus infections among captive and wild populations of Missouri River sturgeon
}

\author{
T. Kurobe ${ }^{1}$, K. T. Kwak ${ }^{1}$, E. MacConnell ${ }^{2}$, T. S. McDowell ${ }^{1}$, F. O. Mardones ${ }^{3}$, \\ R. P. Hedrick ${ }^{1, *}$ \\ ${ }^{1}$ Department of Medicine and Epidemiology, and ${ }^{3}$ Center for Animal Disease Modeling and Surveillance (CADMS), \\ School of Veterinary Medicine, University of California, Davis, California 95616, USA \\ ${ }^{2}$ US Fish and Wildlife Service, Fish Health Center, Bozeman, Montana 59715, USA
}

\begin{abstract}
The Missouri River sturgeon iridovirus (MRSIV) is an important factor contributing to losses during the hatchery rearing of juvenile pallid Scaphirhynchus albus and shovelnose S. platorynchus sturgeon. As the virus has not been isolated in cell culture, current detection procedures rely upon a combination of light and electron microscopy. Detection of characteristic virus-infected cells in the integument, usually of the fins, in hematoxylin and eosin (H\&E)-stained tissue sections provides a presumptive finding. Confirmation requires observation by electron microscopy of characteristic doubly enveloped hexagonal virions of the appropriate size in the host cell cytoplasm. To improve these diagnostic procedures, a conventional polymerase chain reduction (PCR) assay was developed as a sensitive and specific method for detection of MRSIV DNA as found in numerous tissues of both naturally and experimentally infected pallid and shovelnose sturgeon. Sequences of amplicons obtained from testing of wild-caught shovelnose sturgeon and juvenile pallid sturgeon during hatchery outbreaks were identical, suggesting that the viruses found in both sturgeon are similar or closely related. In addition, a TaqMan PCR was developed that allowed estimates of the concentrations of MRSIV DNA present in the tissues of pallid and shovelnose sturgeon during acute and persistent infection. These new PCR assays are improved methods to detect MRSIV, but equally importantly, they provide insights into to the biology of the agent for more effective management of viral diseases in captive and wild Missouri River sturgeon populations.
\end{abstract}

KEY WORDS: Fish iridovirus · Pallid sturgeon - Shovelnose sturgeon - Missouri River sturgeon iridovirus $\cdot$ MRSIV $\cdot$ Diagnostic PCR $\cdot$ Real-time PCR

\section{INTRODUCTION}

Large double-stranded DNA viruses, commonly referred to as iridoviruses, have been found as the cause of serious infections of the integument with resultant mortality of several species of sturgeon. The white sturgeon iridovirus (WSIV) was the first to be described as associated with losses among hatcheryreared juvenile white sturgeon Acipenser transmontanus in California, USA (Hedrick et al. 1990). The virus has also been observed among hatchery and wild white sturgeon found in the Pacific Northwest of the
United States and Canada (LaPatra et al. 1994, Raverty et al. 2003). Outbreaks due to WSIV continue among juvenile white sturgeon in hatcheries that utilize both domestic and wild broodstocks, likely due to either vertical transmission and/or stressors in the hatchery environment (LaPatra et al. 1996, Georgiadis et al. 2000, 2001, Drennan et al. 2005, 2006). The principal site of virus infection is the skin, although the epithelium of the gills also contains numerous hypertrophied virus-infected cells with a characteristic amphophilic to basophilic appearance in hematoxylin and eosin (H\&E)-stained tissue sections (Hedrick et al. 1990). 
These enlarged cells have been shown to contain numerous cytoplasmic virions (Hedrick et al. 1990, Watson et al. 1998). The isolation of WSIV with cell lines developed from host origin has allowed further virus characterization and development of improved diagnostic methods, including a PCR test (Hedrick et al. 1991, 1992, Kwak et al. 2006). The presence of viruses similar to WSIV has also been reported as the cause of serious infections of the integument of Russian sturgeon A. guldenstadi, lake sturgeon A. fluvescens, and Italian sturgeon A. naccarii (Adkison et al. 1998, authors' unpubl. data) and most recently from pallid Scaphirhynchus albus and shovelnose S. platorhynchus sturgeon (Kurobe et al. in press). Unlike WSIV, none of these viruses have been isolated in cell culture, even when newly developed cell lines of host origin have been employed (authors' unpubl. data).

Compromised habitats and overfishing have resulted in declines among many species of sturgeon throughout their holarctic distribution (Birstein 1993). The pallid and shovelnose sturgeon are 2 species indigenous to the Missouri and Mississippi Rivers and their tributaries in the USA (Duffy et al. 1996, Bemis \& Kynard 1997, Kapuscinski 2002). Pallid sturgeon have been the most impacted and are currently listed as endangered (Braaten et al. 2009), and a restoration program involving supplementation of wild populations with hatchery-reared fish has been underway since 1998. Investigations of mortality experienced by juvenile pallid and shovelnose sturgeon have identified an iridovirus, designated as the Missouri River sturgeon iridovirus (MRSIV), as a significant pathogen (Kurobe et al. in press). Despite the inability to isolate the virus in cell culture, many characteristics of the agent and the disease, including routes of transmission and the establishment of a carrier state, have been recently described (Kurobe et al. in press).

In the present study, we report the development of new PCR assays to detect MRSIV DNA in experimentally and naturally infected populations of Missouri
River sturgeon. The initial application of these new conventional and quantitative PCR tests has provided insights into key target tissues and levels of virus present during acute and or persistent virus infections of pallid and shovelnose sturgeon. These new tests will directly assist management strategies aimed at minimizing the potential disease impacts of the MRSIV when using hatchery-reared juveniles for the supplementation or recovery of threatened or endangered populations of pallid sturgeon in the Missouri River drainage.

\section{MATERIALS AND METHODS}

Initial cloning of MRSIV genomic DNA fragments. Pectoral fin samples from pallid sturgeon with MRSIV infections as confirmed by histologic and electron microscopic exams were obtained from the Gavins Point National Fish Hatchery (NFH), Yankton, South Dakota, USA, in 2001 (Kurobe et al. in press). Genomic DNA was extracted from a pool of 3 pectoral fins using a QIAamp DNA Mini kit according to the manufacturer's instructions (Qiagen). Approximately $300 \mathrm{ng}$ of the genomic DNA was then used for PCR with degenerate primers based upon conserved amino acid sequence motifs for the viral DNA polymerase (Knopf 1998) for members of the Herpesviridae (GenBank accession \#AAA66438), Phycodnaviridae (GenBank accession \#AAA88827), and Iridoviridae (GenBank accession \#BAA28669). The conserved amino acid motifs SLYPSII and YGDTD and the respective DNA sequence were utilized as a target for the degenerate PCR using the forward primer dDPf and reverse primer $\mathrm{dDPr}$ (Table 1). The PCR cocktail for a reaction mixture of $50 \mu$ included: $200 \mu \mathrm{M}$ of dNTPs, $1.5 \mathrm{mM}$ of $\mathrm{MgCl}_{2}$, 40 pmol of each primer, 1 unit Platinum ${ }^{\circledR}$ Taq DNA polymerase (Invitrogen) and $5 \mu \mathrm{l}$ of $10 \times$ buffer. The cycling conditions were as follows: initial denaturation step of $95^{\circ} \mathrm{C}$ for $5 \mathrm{~min}$, then 40 cycles of $95^{\circ} \mathrm{C}$ for $30 \mathrm{~s}$, $37^{\circ} \mathrm{C}$ for $30 \mathrm{~s}$, and $72^{\circ} \mathrm{C}$ for $1 \mathrm{~min}$, followed by a final

Table 1. Degenerate primers developed for the amplification of the viral DNA polymerase sequence and specific primers designed to a putative serpin gene sequence found in genomic DNA of the Missouri River sturgeon iridovirus (MRSIV). The MRSIV serpin gene was unintentionally obtained by the primer sets designed for DNA polymerase genes based on an alignment of Herpesviridae (GenBank accession \#AAA66438), Phycodnaviridae (accession \#AAA88827), and Iridoviridae (accession \#BAA28669)

\begin{tabular}{|llll|}
\hline Target & Primer & Sequence (5' to 3') & Product size (bp) \\
\hline MRSIV polymerase gene & $\begin{array}{l}\text { dDPf } \\
\text { dDPr }\end{array}$ & $\begin{array}{l}\text { CTG TAT AYC CBA GBA THA TC } \\
\text { ATR CCS CTR TGS CTG AG }\end{array}$ & 1191 \\
MRSIV serpin gene & MRSIV1043F & GTC CAC TGT TGA TAC TAA GCC TGC & 340 \\
& MRSIV1382R & TAC CTC TAC ATT TCC ACT CCA CC & \\
Sturgeon gonadotropin I & Gnd326F & ATG GCA TCG GTT CTG TTT TG & $\sim 390$ (cDNA) \\
& Gnd327R & CTA GTC CTC CTG GCT GAA GC & \\
\hline
\end{tabular}


extension step at $72^{\circ} \mathrm{C}$ for $5 \mathrm{~min}$, then held at $4^{\circ} \mathrm{C}$. The PCR products were separated and then excised from $2 \%$ agarose gels and DNA recovered with a QIAEX II gel extraction kit (Qiagen). The extracted DNA was ligated into pGEM-T Easy vector (Promega BioSciences) for transformation of Escherichia coli DH5 $\alpha$ competent cells (Invitrogen). The plasmid containing the inserted fragment was extracted using QIAprep Spin Mini Kit (Qiagen) according to the manufacturer's instructions. The sequence of the inserted fragment was determined using M13 forward and reverse primers by fluorescently labeled dideoxy terminator sequencing using an ABI 377 automated DNA sequencer (Applied Biosciences) from 3 clones carrying the suspected MRSIV genomic DNA fragment. Evidence that the putative MRSIV genomic fragment was of viral rather than host origin was deduced by the inability to amplify fragment-specific sequences from uninfected pallid and shovelnose sturgeon tissues as taken directly from fish (pectoral fins) or cell lines established from each fish species.

Development of conventional PCR assay for MRSIV. Specific primer sets for the MRSIV diagnostic PCR were designed with the assistance of Amplify version 1.2 (http://engels.genetics.wisc.edu/amplify/) from the MRSIV genomic fragment. A range of concentrations of the PCR reagents and annealing temperatures were examined for optimum amplification. These included: primer concentrations of $10,20,30$, or $40 \mathrm{pmol}_{i} \mathrm{MgCl}_{2}$ at either $0.5,1.5,2.0$, or $2.5 \mathrm{mM}_{\text {; }}$ and Platinum ${ }^{\circledR}$ Taq polymerase at $0.5,1.0,1.25$, or 1.5 units; PCR cycles of 35 or 40 ; and annealing temperatures of $50,55,60$, or $65^{\circ} \mathrm{C}$. Following the PCR, $10 \mu \mathrm{l}$ of the reaction mixture was examined by electrophoresis for $30 \mathrm{~min}$ on a $2 \%$ agarose gel. The gel was stained with a $0.1 \%$ ethidium bromide solution and then observed with a UV transilluminator.

The detection limit (analytic sensitivity) of the optimized MRSIV diagnostic PCR assay was examined using 10-fold serial dilutions of plasmid DNA harboring the target sequence representing $1 \times 10^{5}$ to $1 \times 10^{-1}$ copies per reaction. The plasmid with the MRSIV genomic DNA fragment was obtained by amplification of the target sequence from DNA extracted from the pectoral fin of a pallid sturgeon naturally infected with MRSIV. The forward primer, MRSIV1043, and reverse primer, MRSIV1382, were used to amplify a 340 bp fragment of the putative MRSIV genomic region (Table 1). The PCR cocktail (50 $\mu \mathrm{l})$ contained $200 \mu \mathrm{M}$ of dNTPs, $1.5 \mathrm{mM}$ of $\mathrm{MgCl}_{2}, 40 \mathrm{pmol}$ of each primer, 1 unit Platinum ${ }^{\circledR}$ Taq DNA polymerase, and $10 \times$ buffer at $1 / 10$ the volume. The PCR cycling conditions were as follows: initial denaturation step of $95^{\circ} \mathrm{C}$ for $5 \mathrm{~min}$, then 40 cycles of $95^{\circ} \mathrm{C}$ for $30 \mathrm{~s}, 60^{\circ} \mathrm{C}$ for $30 \mathrm{~s}$, and $72^{\circ} \mathrm{C}$ for $30 \mathrm{~s}$, followed by a final extension step at $72^{\circ} \mathrm{C}$ for
5 min, and then held at $4^{\circ} \mathrm{C}$. The PCR product was cloned into a vector and sequenced as described in 'Initial cloning of MRSIV genomic DNA fragments'. The copy number of the plasmid DNA was calculated according to the molecular weight and the concentration converted into the copy number based on Avogadro's number $\left(1 \mathrm{~mol}=6.022 \times 10^{23}\right.$ molecules $)$. To test the influence of sturgeon genomic DNA on the PCR, 300 ng of genomic DNA extracted from a cell line established from pallid sturgeon gills (authors' unpubl. data) was added to the cocktail for each PCR.

The analytic specificity of the PCR was examined with DNA from WSIV (Kwak et al. 2006), a Frog virus 3 (FV-3)-like ranavirus isolated from pallid sturgeon at a hatchery in Missouri, USA (authors' unpubl. data) and 3 herpesviruses, the shortnose sturgeon herpesvirus (SSHV) from shortnose sturgeon Acipenser brevirostrum, Acipenserid herpesvirus 1 (AciHV1) and AciHV2 both from white sturgeon (Kurobe et al. 2008). Approximately $10 \mathrm{ng}$ of the genomic DNA of WSIV, pallid sturgeon ranavirus, AciHV1 and 2 were obtained from supernatant of viral infected cells was used for evaluation of the optimized PCR assay for MRSIV.

Development of TaqMan PCR for MRSIV. The primers and the probe for the MRSIV TaqMan PCR assay were designed using Primer Express version 3.0 software (Applied Biosystems) based on sequence of the MRSIV genomic fragment (GenBank accession \#HQ176497) obtained in the present study (Table 2). The target sequence chosen for the primers and the probe was a conserved region identified from 5 isolates of MRSIV (DNA from infected fish tissues) collected from captive pallid sturgeon and wild shovelnose sturgeon from the Missouri River. The probe was labeled with the fluorescent reporter FAM (6-carboxy-fluorescein) at the $5^{\prime}$ end and with the minor groove binding (MGB) quencher at the 3 ' end. The components of the PCR cocktail are listed in Table 3 . The reaction cocktail was placed in MicroAmp fast optical 48-well reaction plates and sealed with MicroAmp 48-well optical adhesive film (Applied Biosystems). The TaqMan PCR assays were run using a StepOne Real-Time PCR system (Applied Biosystems). The PCR program was determined according to the optimal condition for the primers and the probe as designed by Primer Express version 3.0 software: $50^{\circ} \mathrm{C}$ for $2 \mathrm{~min}, 95^{\circ} \mathrm{C}$ for $10 \mathrm{~min}$, 40 cycles of $95^{\circ} \mathrm{C}$ for $15 \mathrm{~s}$, and $60^{\circ} \mathrm{C}$ for $60 \mathrm{~s}$.

The analytical sensitivity of the MRSIV TaqMan PCR assay was examined with serial dilutions of the plasmid DNA used for development of the conventional assay as described in 'Development of conventional PCR assay for MRSIV' $\left(1 \times 10^{7}\right.$ through 10 copies per reaction). Water was added as a negative control. Amplification efficiency and $\mathrm{R}^{2}$ were calculated by StepOne software version 2.0 (Applied Biosystems). 
Table 2. Primers and probes for the TaqMan PCR assay for detection of Missouri River sturgeon iridovirus (MRSIV) and the host gene gonadotropin I from pallid and shovelnose sturgeon

\begin{tabular}{|c|c|c|c|}
\hline Target & Primer/Probe & Use & Sequence $\left(5^{\prime}\right.$ to $\left.3^{\prime}\right)$ \\
\hline MRSIV & $\begin{array}{l}\text { MRSIV-251f } \\
\text { MRSIV-319r } \\
\text { MRSIV-271p }\end{array}$ & $\begin{array}{l}\text { Forward primer } \\
\text { Reverse primer } \\
\text { Probe }\end{array}$ & $\begin{array}{l}\text { CCA TGC TAG TGC GGC AGA T } \\
\text { CCA AAT GAT TCA AGA TAA TAA GTC CAA GA } \\
\text { AAG CGT ATA TTG TCC TCT G }\end{array}$ \\
\hline Sturgeon gonadotropin I & $\begin{array}{l}\text { StgGnd-880f } \\
\text { StgGnd-937r } \\
\text { StgGnd-899p }\end{array}$ & $\begin{array}{l}\text { Forward primer } \\
\text { Reverse primer } \\
\text { Probe }\end{array}$ & $\begin{array}{l}\text { TGT GGC GCT CAG CTG TGA } \\
\text { AGG GTG CCA CAG TCA GTG TAG TC } \\
\text { TGT GGC CAG TGT GCC A }\end{array}$ \\
\hline
\end{tabular}

Table 3. Components of TaqMan PCR assays for Missouri River sturgeon iridovirus serpin and sturgeon gonadotropin I gene. UNG: uracil-N-glycosylase

\begin{tabular}{|lc|}
\hline Components & $\begin{array}{c}\text { Volume per reaction } \\
(12 \mu \mathrm{l})\end{array}$ \\
\hline $2 \times$ TaqMan Universal Master & $6 \mu \mathrm{l}$ \\
Mix with UNG ${ }^{\mathrm{a}}$ & \\
Primers $(20 \mu \mathrm{M})$ & $0.24 \mu \mathrm{l}$ each \\
& $(400 \mathrm{nM}$ each $)$ \\
Probe $(10 \mu \mathrm{M})$ & $0.096 \mu \mathrm{l}$ \\
& $(80 \mathrm{nM})$ \\
Water & $0.65 \mu \mathrm{l}$ \\
DNA sample ${ }^{\mathrm{b}}$ & $5 \mu \mathrm{l}$ \\
${ }^{\mathrm{a}}$ Applied Biosystems & \\
${ }^{\mathrm{b}}$ Concentration of genomic DNA less than $300 \mathrm{ng} \mathrm{\mu l}^{-1}$ \\
\hline
\end{tabular}

The amplification efficiency and threshold cycle $\left(C_{\mathrm{T}}\right)$ values were compared with or without the addition of genomic DNA (300 ng per reaction) extracted from uninfected fish to evaluate the potential influence of fish DNA in the reaction.

Development of TaqMan PCR assay for the fish gene gonadotropin I. A second TaqMan PCR assay was developed for a host (pallid and shovelnose sturgeon) gene to allow for calculations of the number of host cells present in each assay (Gilad et al. 2004). Cloning of the host genes from pallid and shovelnose sturgeon were conducted as follows: A primer set for conventional PCR, forward primer, Gnd326F, and reverse primer, Gnd327R (Table 1), was designed for the gonadotropin I $\beta$ subunit gene from Amur sturgeon Acipenser schrenckii (GenBank accession \#AY575920). PCR was performed with genomic DNA extracted from cell lines derived from pallid and shovelnose sturgeon gills (authors' unpubl. data) as template DNA. The PCR cycling conditions were as follows: initial denaturation step of $95^{\circ} \mathrm{C}$ for $5 \mathrm{~min}$, then 30 cycles of $95^{\circ} \mathrm{C}$ for $30 \mathrm{~s}, 55^{\circ} \mathrm{C}$ for $30 \mathrm{~s}$, and $72^{\circ} \mathrm{C}$ for $1 \mathrm{~min}$, followed by a final extension step at $72^{\circ} \mathrm{C}$ for $5 \mathrm{~min}$, and then held at $4^{\circ} \mathrm{C}$. Components of the reaction cocktail and the procedure for cloning PCR products were the same as described in 'Initial cloning of MRSIV genomic DNA fragments'. The amplified DNA fragments were analyzed by similarity search with the BLASTN program (GenBank), and alignments were generated using ClustalW program version 1.83 (Thompson et al. 1994).

The primers and the probe for the TaqMan PCR assay for a region of the open reading frame for the gonadotropin I gene were designed using Primer Express version 3.0 software as indicated in Table 2. The probe, StgGnd-899p, was labeled with the fluorescent reporter FAM at the 5' end and with the MGB quencher at the $3^{\prime}$ end. A standard curve was generated by running the TaqMan PCR assay on serial dilutions of plasmid DNA harboring the target sequence amplified from pallid sturgeon with the forward primer, Gnd-326F, and reverse primer, Gnd-327R (Table 1). Conditions for the reaction were identical to those described for the TaqMan assay for the genomic fragment of MRSIV.

Southern blotting was conducted to demonstrate the copy number of the gonadotropin I gene for pallid and shovelnose sturgeon. Approximately $20 \mu \mathrm{g}$ of genomic DNA extracted from pallid and shovelnose sturgeon cell lines was digested with $60 \mathrm{U}$ of $S a c$ I restriction enzyme overnight at $37^{\circ} \mathrm{C}$. Digested DNA was separated on a $0.8 \%$ gel and then transferred to a nylon membrane (Roche). The pallid sturgeon gonadotropin I $\beta$ subunit gene fragment (approximately $600 \mathrm{bp}$, no SacI site) was labeled with digoxigenin (DIG) using DIG high prime DNA labeling and Detection Starter Kit I (Roche) and then used for hybridization. The hybridization reaction was performed according to the manufacturer's instructions.

Examination of sturgeon with experimental MRSIV infections. Samples from prior experimental exposures of juvenile pallid sturgeon were used as known viruspositive controls for evaluations of the new MRSIV PCR assays. All the exposure studies were conducted prior to the development of the TaqMan PCR, and thus the concentrations of viral DNA in the virus inocula were not determined. The new conventional PCR was compared to histologic detection of MRSIV for experimentally infected sturgeon at 2 mo (Study 1) and 5 mo 
(Study 2) post virus exposure. In Study 3, we compared experimentally infected fish for agreement between the conventional and TaqMan PCR assays for detection of MRSIV DNA in the pectoral fins of sturgeon during the peak period of mortality.

Study 1: Healthy juvenile pallid sturgeon were obtained from the Gavins Point NFH in 2005. Fifty fish (10 $\mathrm{g}, \mathrm{n}=100)$ were placed into each of two $130 \mathrm{l}$ aquaria receiving $13^{\circ} \mathrm{C}$ well water at $0.81 \mathrm{~min}^{-1}$. The method for experimental MRSIV exposures of pallid sturgeon by Kurobe et al. (in press) was employed. Briefly, water flow to aquaria was arrested, and a homogenate prepared from the fins of MRSIV-infected pallid sturgeon was added to one aquaria for a $1 \mathrm{~h}$ static exposure. Fish in the second aquarium served as controls and received only minimal essential media (MEM), the medium used in the homogenization of the MRSIV-infected sturgeon fins. Ten fish from each of the virus-exposed and control aquaria were randomly removed and euthanized with an overdose of benzocaine (500 $\mathrm{mg} \mathrm{l}^{-1}$ ) at 2 mo post virus exposure. A pectoral fin from each fish was placed into a tube and held on ice for later DNA extraction. In addition, one of each of the paired fins (pectoral and pelvic), the dorsal, anal and caudal fin, and a portion of the fleshy edge of the operculum and the tip of the rostrum were placed into a tube with $10 \%$ neutral buffered formalin. The fixed tissues were then processed by standard histological procedures for the preparation of H\&E stained tissue sections (Humason 1979). Fish tissues for this study were collected using tubes labeled by a random number generator, which allowed for blinding during the histological and PCR analyses. For histological analyses, the number of characteristically enlarged and amphophilicstained cells present in each tissue was enumerated in 10 random microscope fields at a total magnification of 200×. A fish was considered positive if virus-infected cells were found in the integument of any of the fins, operculum, or rostrum (Kurobe et al. in press). For PCR analyses, DNA from the pectoral fin was extracted using a Qiagen DNA extraction kit (Qiagen) and the concentration determined by spectrophotometer prior to a conventional PCR to detect MRSIV DNA.

Study 2: A second experimental exposure following methods described in Study 1 was conducted in 2006 with fish from the same lot of healthy pallid sturgeon from Gavins Point NFH. The only variations from Study 1 methods were fish weight $(15 \mathrm{~g})$ at the time of virus exposure and the sampling time at 5 mo rather than 2 mo post virus exposure.

Study 3: A third experimental exposure following methods described in Study 1 and 2 was conducted in 2007 with healthy juvenile sturgeon $(6.0 \mathrm{~g}, \mathrm{n}=200)$ originating from the Garrison Dam NFH, Riverdale, North Dakota, USA. Differences from Study 1 and 2 were source and numbers of fish $(n=100)$ in each of the exposed and control treatments. An additional variation from Study 1 and 2 was sampling focused on fish dying $(\mathrm{n}=44)$ in the virus-exposed treatment during the peak mortality period at 53 to $58 \mathrm{~d}$ post virus exposure. To serve as controls, an equal number of live fish ( $\mathrm{n}=44$ ) was sampled during the same time period from the control aquarium. Concentrations of DNA as extracted from the pectoral fin of each fish were adjusted to approximately $300 \mathrm{ng} \mathrm{\mu l}^{-1}$ for the TaqMan PCR assays for both MRSIV DNA and the sturgeon gonadotropin I gene. The threshold value of the TaqMan PCR was automatically determined by StepOne software version 2.0 to obtain the highest possible correlation coefficient $\left(\mathrm{R}^{2}\right)$ for the standard curve. Host cell copy numbers in each reaction were calculated by dividing the raw copy number for the gonadotropin I gene by 4 since pallid and shovelnose sturgeon are diploid (Ludwig et al. 2001) and possess 2 copies of the gonadotropin I gene per cell based on the results of Southern hybridization in the present study. TaqMan reactions were performed in triplicate for each sample and expressed as the mean copy number. The copy number of MRSIV was expressed as equivalents per $1 \times 10^{6}$ host cells and per $\mu \mathrm{g}$ of host genomic DNA.

Examinations of sturgeon with naturally acquired MRSIV infections. Wild adult shovelnose sturgeon were captured from the same site on the Missouri River near the towns of Virgelle and Loma, Montana, USA, on October $6(n=20)$ and November $16(n=33), 2006$, respectively. The wild shovelnose ranged in size from 66 to $121 \mathrm{~cm}$ in fork length. A clip of $1 \mathrm{~cm}^{2}$ was removed from the pectoral fin of each fish. The tissue was divided with approximately a $2 / 3$ portion placed into Davidson's fixative for standard histological processing. The remaining portion of the pectoral fin was placed into a tube with lysis buffer for subsequent DNA extraction. On the second collection of 33 fish, pectoral fins from 17 fish for DNA extraction were sent to the Western Fisheries Research Center, US Geological Survey, Seattle, Washington, USA, and 16 samples were sent to our laboratory. After DNA extraction, the samples were divided into equal portions, and one portion was sent to the other laboratory such that both laboratories had complete 33 fish sample sets. The samples in both laboratories were examined using the conventional PCR test for MRSIV. Amplicons obtained from 15 fish from the first collection were cloned and sequenced for comparison with the known target sequence from MRSIV from pallid sturgeon. H\&E tissue sections of the pectoral fins from all fish were evaluated for the presence of MRSIV as described in 'Examination of sturgeon with experimental MRSIV infections'.

Statistical analyses. The kappa statistic and its 95\% confidence interval (Cohen 1960) was used to evalu- 
ate the level of agreement between the qualitative outcomes obtained from histologic examination compared to PCR detection of MRSIV in Study 1 and 2 and for comparisons of the conventional and TaqMan PCR for wild shovelnose sturgeon. The Pearson's correlation coefficient (Rodgers \& Nicewander 1988) was calculated to measure the degree of dependence or linear relationship between the 2 expressions for viral DNA content (copy number per $10^{6}$ host cells and copy number per $1 \mu \mathrm{g}$ of host genomic DNA) obtained from the TaqMan PCR for detection of MRSIV DNA in experimentally infected pallid sturgeon (Study 3). Copy numbers of viral DNA for each fish were $\log _{10}$ transformed for the normalized assumption. The Student's $t$-test was performed to compare the mean copy numbers of MRSIV DNA between 2 collections of wild adult shovelnose sturgeon.

\section{RESULTS}

\section{Cloning of putative serpin gene of MRSIV}

Although the initial target for PCR amplification with degenerate primers was the viral DNA polymerase, the MRSIV genomic fragment (1191 bp) obtained showed most similarity (45\% deduced amino acid) to the serpin gene of cattle (E-value: 1E-15). The fragment also contained a region (205 bp) which does not show any similarity to other DNA sequences deposited in the GenBank database.

\section{Development of conventional PCR assay for MRSIV}

Optimal amplification as assessed by band strength in stained agarose gels was obtained using the following parameters for the conventional PCR for MRSIV DNA: The template used was $300 \mathrm{ng}$ of DNA extracted from fish tissue. Cycling conditions were $95^{\circ} \mathrm{C}$ for $3 \mathrm{~min}, 95^{\circ} \mathrm{C}$ for $30 \mathrm{~s}, 65^{\circ} \mathrm{C}$ for $1 \mathrm{~min}, 72^{\circ} \mathrm{C}$ for $2 \mathrm{~min}, 39$ cycles, $72^{\circ} \mathrm{C}$ for $7 \mathrm{~min}$. Forward and reverse primer were MRSIV1043F and MRSIV1382R, respectively (Table 1). The size of amplicon was $340 \mathrm{bp}$, and the components of the reaction cocktail are listed in Table 4.

The analytical sensitivity of the conventional PCR assay as determined by serial dilutions of plasmid DNA was 1 copy of the target DNA as present in $300 \mathrm{ng}$ of fish genomic DNA (Fig. 1). Testing of the analytic specificity of the conventional MRSIV PCR assay indicated no evidence for amplification of DNA as obtained from WSIV, a ranavirus from pallid sturgeon, SSHV, AciHV1, or AciHV2 (Fig. 2).
Table 4. Components and their optimised concentrations for the conventional PCR assay developed to amplify Missouri River sturgeon iridovirus (MRSIV) DNA

\begin{tabular}{|c|c|c|}
\hline Component & Volume & $\begin{array}{c}\text { Final } \\
\text { concentration }\end{array}$ \\
\hline $5 \times$ PCR buffer & $5 \mu \mathrm{l}$ & $1 \times$ \\
\hline $10 \mathrm{mM}$ dNTP mixture & $1 \mu \mathrm{l}$ & $0.2 \mathrm{mM}$ each \\
\hline $50 \mathrm{mM} \mathrm{MgCl}_{2}$ & $1.5 \mu \mathrm{l}$ & $1.5 \mathrm{mM}$ \\
\hline $20 \mu \mathrm{M}$ primer & $2 \mu \mathrm{leach}$ & $0.8 \mathrm{mM}$ each \\
\hline DNA polymerase ${ }^{a}$ & $0.25 \mu \mathrm{l}$ & $1.25 \mathrm{U}$ \\
\hline DNA sample ${ }^{b}$ & $300 \mathrm{ng}$ & \\
\hline Water & Up to $50 \mu \mathrm{l}$ & \\
\hline \multicolumn{3}{|c|}{${ }^{a}$ Platinum ${ }^{\circledR}$ Taq DNA polymerase (Invitrogen) } \\
\hline
\end{tabular}

\section{TaqMan PCR for MRSIV and host gene}

The primers and the probe designed for TaqMan PCR amplification of MRSIV and the sturgeon gonadotropin I gene are listed in Table 2. The optimized cycling conditions for both assays included a holding step at $50^{\circ} \mathrm{C}$ for $2 \mathrm{~min}$, initial denaturation of $95^{\circ} \mathrm{C}$ for $10 \mathrm{~min}$, followed by 40 cycles of denaturation at $95^{\circ} \mathrm{C}$ for $15 \mathrm{~s}$ and annealing extension at $60^{\circ} \mathrm{C}$ for $1 \mathrm{~min}$. The components of the reaction mix are indicated in Table 3 . The analytic sensitivity of the new TaqMan PCR for MRSIV as determined with serial dilutions of plasmid was at least 10 molecules of target DNA as present in $300 \mathrm{ng}$ of fish genomic DNA (Fig. 3A). Testing of the analytical specificity for the MRSIV TaqMan PCR assay demonstrated no evidence for amplification of DNA obtained from white sturgeon cell cultures infected with WSIV, pallid sturgeon ranavirus, SSHV, AciHV1, or AciHV2.

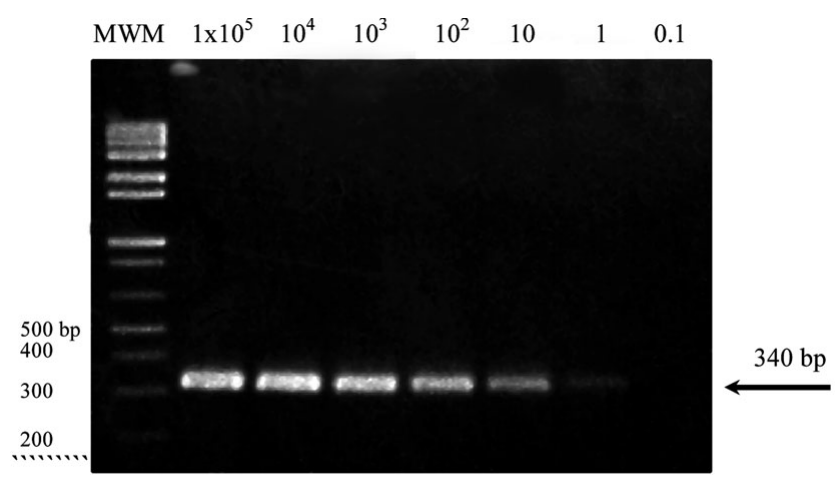

Fig. 1. Ethidium bromide-stained agarose gel demonstrating the analytic sensitivity of the conventional PCR assay for Missouri River sturgeon iridovirus (MRSIV). The detection limit was evaluated with 10 -fold serial dilutions from $1 \times 10^{5}$ to $1 \times$ $10^{-1}$ copies of the plasmid carrying the target sequence as mixed with $300 \mathrm{ng}$ of pallid sturgeon Scaphirhynchus albus genomic DNA. Arrow: expected amplicon size (340 bp), MWM: molecular weight marker 


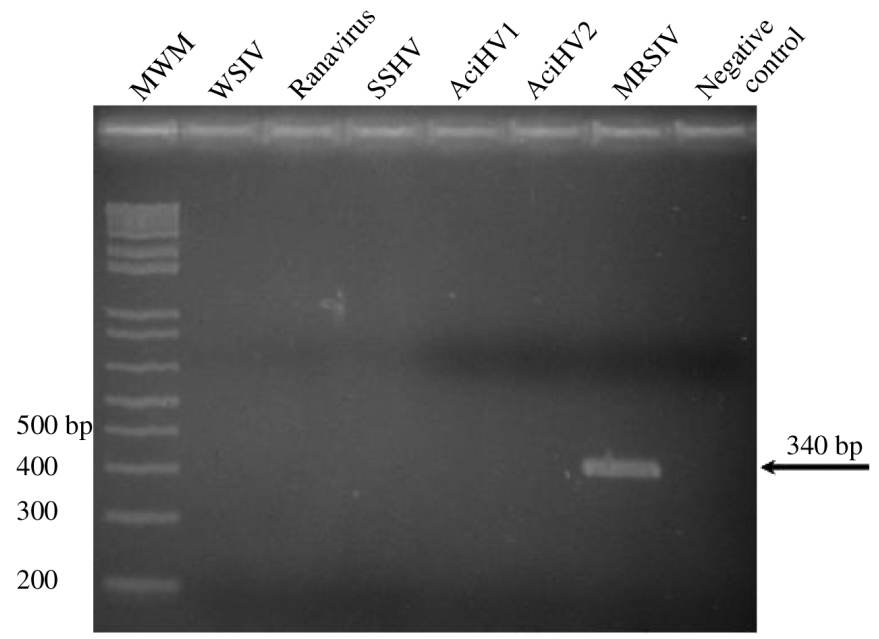

Fig. 2. Examination of the analytic specificity of the conventional PCR assay for Missouri River sturgeon iridovirus (MRSIV) using DNA as obtained from white sturgeon iridovirus (WSIV), a ranavirus from pallid sturgeon, shortnose sturgeon herpesvirus (SSHV), and 2 herpesviruses from white sturgeon, AciHV1 and 2. Amplicon size of $340 \mathrm{bp}$ for MRSIV is indicated for the positive control. MWM: molecular weight marker
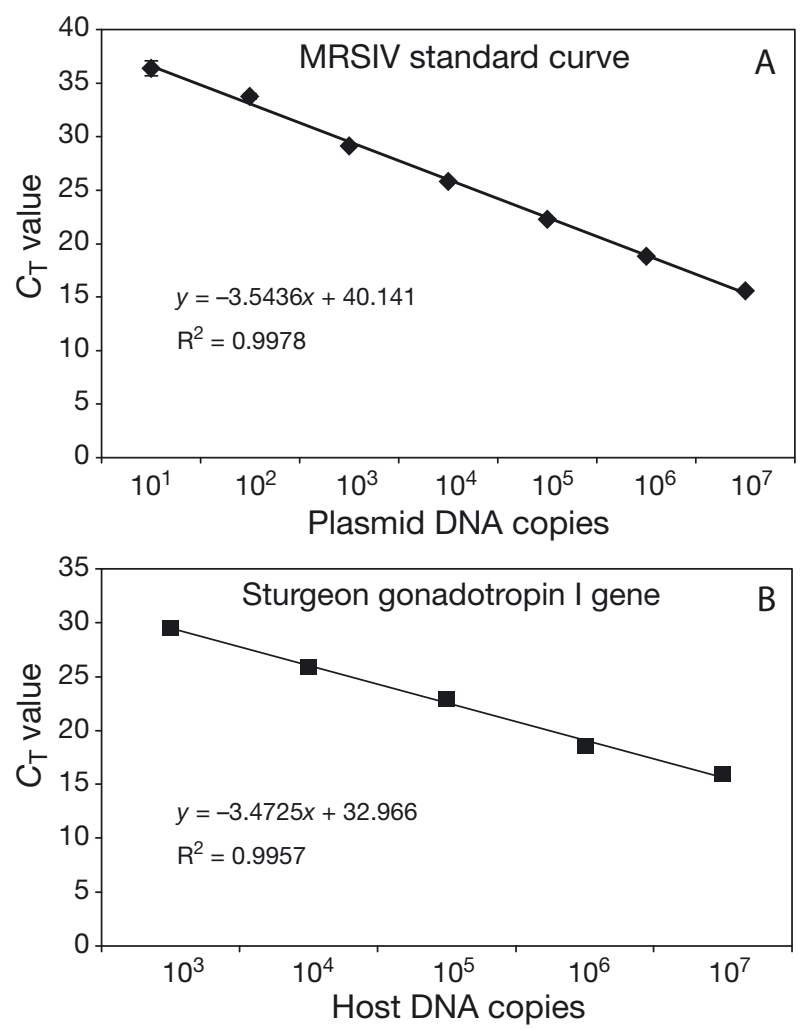

Fig. 3. Standard curves based on the threshold cycle $\left(C_{\mathrm{T}}\right)$ values from the TaqMan PCR assays of serially diluted plasmid DNA of (A) $1 \times 10^{7}$ through 10 copies of Missouri River sturgeon iridovirus (MRSIV) target sequence and (B) $1 \times 10^{7}$ through $1 \times 10^{3}$ copies of target sequences for the host gonadotropin I gene
Nucleotide sequences of portions of the gonadotropin I gene (939 bp) amplified from pallid and shovelnose sturgeon by PCR were deposited in GenBank database (pallid sturgeon gonadotropin I $\beta$ (accession \#HQ176498) and shovelnose sturgeon I $\beta$ (accession \#HQ176499). The amplified fragment was longer than expected when compared to the cDNA sequence (approximately $350 \mathrm{bp}$ ) due to the presence of one intron (data not shown). Southern blotting performed with PstI-digested pallid and shovelnose sturgeon genomic DNA using a 600 bp (no PstI site) gonadotropin fragment as a probe revealed 2 bands at approximately 6.5 and $5.0 \mathrm{~kb}$ (data not shown). This suggests that 2 copies of the gonadotropin I gene are present in the sturgeon genome. PCR was conducted using these 2 bands as template from pallid and shovelnose sturgeon, and an alignment was generated based on the obtained sequences. Although there were some minor base differences observed in the gene from pallid and shovelnose sturgeon, none were observed in the target region used for the TaqMan PCR (data not shown). The standard curve generated with serial dilutions of the plasmid DNA harboring the target sequence is shown in Fig. 3B $\left(1 \times 10^{7}\right.$ through $1 \times 10^{3}$ copies per reaction $)$.

\section{Examination of sturgeon with experimental MRSIV infections}

Study 1 (2 mo post virus exposure)

All 10 fish sampled from the virus-exposed treatment were found positive by histology (Table 5). Virus-infected cells were observed in all of the tissues sampled from 5 fish with the pelvic fin as the most frequent site of infection (9/10) followed closely by the pectoral fin, operculum, and rostrum (8/10). The greatest concentrations of virus-infected cells were found in the operculum, followed by pelvic and pectoral fins. There was no evidence for virus-infected cells in tissues sampled from 10 control fish. The conventional PCR for MRSIV was positive for the pectoral fins from all 10 virus-exposed fish and negative for all 10 control fish. There was perfect agreement (kappa = 1.0) between the 2 tests for detection of MRSIV in virus-exposed sturgeon.

\section{Study 2 (5 mo post virus exposure)}

There was no evidence by histology for virusinfected cells in any of the tissue sites of the MRSIVexposed or the control sturgeon sampled at 5 mo post exposure. The conventional PCR for MRSIV detected viral DNA in the pectoral fins of 5/10 virus-exposed 
Table 5. Scaphirhynchus albus. Comparison of the conventional PCR assay and histology for detection of Missouri River sturgeon iridovirus (MRSIV) among experimentally infected juvenile pallid sturgeon examined at 2 mo post virus exposure (Study 1). Seven tissue sites including pectoral, pelvic, dorsal, anal, and caudal fins and the operculum and rostrum were sampled for each fish and then examined for the presence and number of virus-infected cells in stained tissue sections. DNA extracted from the pectoral fin was examined for presence of MRSIV DNA by PCR. There was no evidence of virus-infected cells or MRSIV DNA found in 10 control unexposed pallid sturgeon

\begin{tabular}{|c|c|c|c|c|c|c|c|c|}
\hline \multirow{2}{*}{ Fish no. } & \multirow{2}{*}{ PCR result } & \multicolumn{7}{|c|}{ Histology tissue sites (no. infected cells ${ }^{\mathrm{a}}$ ) } \\
\hline & & Pectoral & Pelvic & Dorsal & Anal & Caudal & Operculum & Rostrum \\
\hline 1 & + & 2 & 7 & 8 & 3 & 4 & 9 & 6 \\
\hline 2 & + & 7 & 1 & 10 & 1 & 18 & 3 & 1 \\
\hline 3 & + & 2 & 1 & 0 & 0 & 3 & 6 & 2 \\
\hline 4 & + & 11 & 13 & 1 & 15 & 9 & 10 & 6 \\
\hline 5 & + & 4 & 10 & 2 & 3 & 6 & 6 & 3 \\
\hline 6 & + & 10 & 5 & 1 & 0 & 0 & 4 & 0 \\
\hline 7 & + & 0 & 2 & 0 & 4 & 0 & 0 & 1 \\
\hline 8 & + & 3 & 1 & 10 & 1 & 0 & 11 & 4 \\
\hline 9 & + & 0 & 0 & 0 & 1 & 0 & 0 & 4 \\
\hline 10 & + & 2 & 3 & 0 & 0 & 8 & 2 & 0 \\
\hline
\end{tabular}

sturgeon. There was no evidence of viral DNA in any of the 10 control sturgeon examined with the conventional MRSIV PCR assay. There was no agreement (kappa $=0$ ) between results obtained for the histology and PCR detection of MRSIV among sturgeon 5 mo following experimental exposures to the virus.

\section{Study 3}

The pectoral fin samples from all juvenile pallid sturgeon $(\mathrm{n}=44$ ) dying following an experimental exposure to MRSIV were found positive with the newly developed TaqMan PCR assay. In contrast, 44 fish examined from the control unexposed group were all negative $\left(C_{\mathrm{T}}>40\right)$. The $\log _{10}$ mean copy number of MRSIV target DNA per $\mu \mathrm{g}$ of genomic DNA was 4.2 (95\% CI $=4.1,4.3)$. Alternatively, the $\log _{10}$ mean copy number of MRSIV target DNA per $10^{6}$ host cells was $5.3(95 \% \mathrm{CI}=5.1,5.4)$. There was a strong and significant correlation coefficient $(\mathrm{r}=0.94, \mathrm{p}<0.001)$ between the 2 units (per $10^{6}$ host cells or per $\mu \mathrm{g}$ of host DNA) used to express the copy numbers of viral DNA detected (Fig. 4).

\section{Comparisons of diagnostic methods with wild shovelnose sturgeon}

The pectoral fins collected from nonlethal sampling of wild adult shovelnose sturgeon $(\mathrm{n}=53)$ were examined by histological, conventional, and TaqMan PCR detection methods for MRSIV. All wild shovelnose sturgeon sampled were healthy in appearance and, following length measurements and pectoral fin clipping, were released into the river. There was no evidence of virus-infected cells found by histology in the pectoral fin clips from any wild shovelnose sturgeon from either collection date. From the first fish collection, the conventional PCR detected MRSIV DNA in 15 of 20 fish and the TaqMan PCR in 19 of 20 fish (Table 6) with the $\log _{10}$ mean virus copy number per $\mu \mathrm{g}$ of DNA $=2.5$ (95\% CI $=2.0$ to 3.1$)$. Sequencing of the amplicons from all 15 fish indicated near identity (1 bp difference) with the putative serpin gene fragment from MRSIV-infected pallid sturgeon. In the second fish collection ( $\mathrm{n}=33$ ), MRSIV DNA

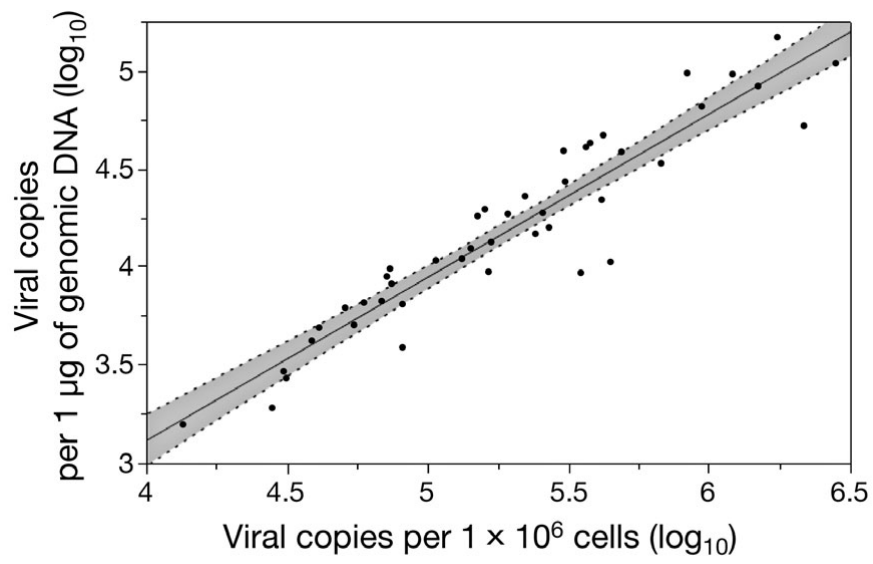

Fig. 4. Fitted line and $95 \%$ CI for the relationship between 2 expression methods for viral copy numbers for Missouri River sturgeon iridovirus (MRSIV). The pectoral fins removed from dying pallid sturgeon $(\mathrm{n}=44)$ following virus exposure (Study 3) were analyzed by the MRSIV and host gene TaqMan PCR assays. The units of expression were the $\log _{10}$-transformed virus copies $\mu \mathrm{g}$ of $\mathrm{DNA}^{-1}$ or $10^{-6}$ host cells. Pearson's correlation coefficient $(\mathrm{r}=0.94, \mathrm{p}<0.001)$ indicates the high degree of correlation between the 2 expressions for virus copy numbers 
Table 6. Scaphirhynchus platorynchus. Detection and $\log _{10}$ copy numbers of Missouri River sturgeon iridovirus (MRSIV) DNA as found in the pectoral fins of 2 groups of wild adult shovelnose sturgeon from the Missouri River on October 6, 2006 (Collection 1) and on November 16, 2006 (Collection 2) using the conventional PCR and TaqMan PCR assays. The viral copy number is expressed as per $\mu \mathrm{g}$ of host DNA

\begin{tabular}{|c|c|c|}
\hline Fish no. & $\begin{array}{c}\text { Conventional } \\
\text { PCR }\end{array}$ & $\begin{array}{l}\text { TaqMan PCR } \\
\text { (viral copy no.) }\end{array}$ \\
\hline \multicolumn{3}{|c|}{ Collection 1} \\
\hline 1 & + & 3.6 \\
\hline 2 & + & 4.5 \\
\hline 3 & + & 2.4 \\
\hline 4 & + & 3.3 \\
\hline 5 & + & 3 \\
\hline 6 & + & 4.2 \\
\hline 7 & + & 3.3 \\
\hline 8 & + & 3.5 \\
\hline 9 & - & - \\
\hline 10 & + & 3.2 \\
\hline 11 & - & 0.6 \\
\hline 12 & + & 2 \\
\hline 13 & - & 1.1 \\
\hline 14 & + & 1.6 \\
\hline 15 & + & 2.2 \\
\hline 16 & + & 1.8 \\
\hline 17 & + & 3.2 \\
\hline 18 & - & 1.5 \\
\hline 19 & + & 3.7 \\
\hline \multirow[t]{2}{*}{20} & - & 2.3 \\
\hline & $15 / 20$ positive & Average 2.5 \\
\hline \multicolumn{3}{|c|}{ Collection 2} \\
\hline 1 & - & 1 \\
\hline 2 & - & 1.7 \\
\hline 3 & - & - \\
\hline 4 & - & - \\
\hline 5 & - & 0.7 \\
\hline 6 & - & 1.2 \\
\hline 7 & - & 0.8 \\
\hline 8 & - & 0.6 \\
\hline 9 & - & - \\
\hline 10 & - & - \\
\hline 11 & + & 2.8 \\
\hline 12 & - & 0.5 \\
\hline 13 & - & - \\
\hline 14 & - & 0.6 \\
\hline 15 & - & - \\
\hline 16 & + & 3.3 \\
\hline 17 & - & 0.6 \\
\hline 18 & + & 2.5 \\
\hline 19 & + & 1.3 \\
\hline 20 & - & 1.7 \\
\hline 21 & - & 0.9 \\
\hline 22 & + & 0.7 \\
\hline 23 & - & - \\
\hline 24 & - & 1.6 \\
\hline 25 & + & 1.2 \\
\hline 26 & + & 2.4 \\
\hline 27 & - & 1.8 \\
\hline 28 & - & 1.4 \\
\hline 29 & - & - \\
\hline 30 & - & 0.8 \\
\hline 31 & + & 1.8 \\
\hline 32 & + & 1.5 \\
\hline \multirow[t]{2}{*}{33} & + & 2.4 \\
\hline & 10/33 positive & Average 1.1 \\
\hline
\end{tabular}

was detected by the conventional PCR in 10 fish and by the TaqMan PCR in 25 fish with the $\log _{10}$ mean virus copy number per $\mu \mathrm{g}$ of DNA $=1.1(95 \% \mathrm{CI}=$ 0.8 to 1.4 ). The mean copy numbers of MRSIV DNA were significantly less in fish from the second than from the first collection $(p<0.001)$. Performance of the conventional PCR for MRSIV in shared samples between 2 laboratories was consistent with agreement on the classification of 32 of 33 fish. The kappa statistic for comparisons of the conventional and TaqMan PCR assays for MRSIV examined from the first fish collection was 0.27 (95\% CI $=-0.16$ to 0.71$)$. A kappa of 0.24 (95\% CI $=0.06$ to 0.43$)$ was obtained for comparisons of the 2 PCR methods with the second collection of wild shovelnose sturgeon.

\section{DISCUSSION}

MRSIV has emerged as a key factor contributing to losses during the hatchery rearing of juvenile pallid Scaphirhynchus albus and shovelnose S. platorynchus sturgeon. Two new PCR assays were developed that allow detection as well as quantification of MRSIV DNA levels in the tissues of naturally and experimentally infected pallid and shovelnose sturgeon. Initial validation steps indicated that both tests show good analytic sensitivity and specificity and the conventional PCR provided reproducible results in an inter-laboratory comparison. Both assays detected MRSIV DNA in experimentally and naturally infected sturgeon populations during acute or subclinical infection, and in the latter case when histological detection was consistently negative. The application of these new PCR assays provide an improved means to detect and manage MRSIV infections in hatchery populations of pallid and shovelnose sturgeon involved in restoration programs for Missouri River sturgeon.

The original viral gene targeted for amplification from MRSIV was the DNA polymerase. However, the amplicon obtained with the designed primers was clearly unrelated to known viral DNA polymerases, showing instead a relationship to the serpin gene of cattle. Serpins are involved in a wide range of biological responses including inflammation via their inhibitory effects on serine proteases, and gene homologs have been identified in animals, plants, bacteria, and viruses (Law et al. 2006). Viral serpins as immunomodulators of the host inflammatory response and apoptosis inhibitors have been described as means for poxviruses to evade the host immune response (Guerin et al. 2001). There are no current reports of serpin genes among fish viruses, including iridoviruses where the entire genomes have been sequenced (Song 
et al. 2004). A MRSIV serpin-like gene homolog may also be absent from WSIV, a virus from sturgeon with similarities to MRSIV as indicated by the specificity of the new MRSIV PCR test. That the putative serpin gene sequence is of MRSIV and not host origin was demonstrated by consistent amplification of the expected fragment using primers designed to this sequence from known MRSIV-infected tissues but never from control pallid or shovelnose sturgeon or cell lines derived from each fish species.

Both new PCR assays for MRSIV demonstrated adequate analytic sensitivity and specificity providing assurance that a range from relatively low (e.g. 10) to higher copy numbers of MRSIV DNA could be detected without nonspecific amplification of other known viral agents described from sturgeon (Figs. 1 to 3).

The conventional MRSIV PCR assay also showed that viral DNA can be detected during different stages of MRSIV infection. In Study 1, MRSIV infections were approaching the acute phase ( 2 mo post exposure), and as a result there was perfect agreement (kappa $=1.0$ ) between the conventional PCR and histologic detection methods for MRSIV (Table 5). Study 1 also provided evidence that the use of fin samples (e.g. pectoral fins), parts, or punches of which can be removed nonlethally, provide a good site for detection of MRSIV during or just preceding the onset of acute viral infections. The integument of the fins, either for histology or PCR examinations, has also been shown to be a suitable tissue for detection of WSIV in white sturgeon with naturally occurring or experimental infections (LaPatra et al. 1994, Watson et al. 1998, Kwak et al. 2006). The persistence of MRSIV infections in fish recovering from acute infections was confirmed by detection of viral DNA at 5 mo post virus exposure (Study 2). In contrast to Study 1, in Study 2, histology was a less reliable indicator of virus infection status, with a kappa statistic $=0$, which indicates a nil level of agreement between the 2 detection methods (Viera \& Garrett 2005). All fish in Study 2 were healthy in appearance by 5 mo post exposure, and we presume that virus concentrations had dropped significantly by this time, which would explain the inability to detect infections by histology. As Studies 1 and 2 were conducted prior to development of the TaqMan PCR for MRSIV, we were unable to confirm this assumption. However, more recent studies by Kurobe et al. (in press) of pallid sturgeon during this persistent phase of virus infection have demonstrated viral DNA copy numbers in pectoral fins can range from 0 to $10^{3}$ per $10^{6}$ host cells.

Quantitative PCR tests generally use 2 types of units for expressing concentrations of target sequence, either copy number per $\mu \mathrm{g}$ of host DNA or per $10^{6}$ host cells (Gilad et al. 2004, Goodwin et al. 2006). The strong correlation $(r=0.94)$ between both types of expressions for MRSIV DNA copy numbers in our Study 3 indicates that either unit is appropriate for expressing DNA concentrations of MRSIV DNA.

The application of the new PCR assays provides evidence for persistent MRSIV infections among wild shovelnose sturgeon that may be routinely missed by histologic exams (Table 6). In the collections of wild shovelnose sturgeon, histology failed to detect any evidence of MRSIV infection, while both PCR tests demonstrated many fish harboring MRSIV DNA with both the conventional and TaqMan PCR in 'fair' agreement (0.27 to 0.24$)$ for properly classifying fish as MRSIV-positive (Viera \& Garrett 2005). A substantial decline in MRSIV-positive fish was encountered in the second collection of wild shovelnose sturgeon, a situation perhaps related to declining water temperatures at this time of year in the Missouri River (K. Staigmiller pers. comm.).

The development of PCR assays has considerably improved the ability to detect and to understand the pathogenesis of several fish viral pathogens including agents which may or may not be propagated in fish cell lines (Boyle \& Blackwell 1991, Gray et al. 1999, Gilad et al. 2002, Bercovier et al. 2005, Kwak et al. 2006, Waltzek et al. 2009, Kurobe et al. 2009, in press). The new PCR assays for MRSIV can be used immediately for surveillance/screening of hatchery and wild stocks of pallid and shovelnose sturgeon and as a replacement for electron microscopy in confirming histologic results during acute infections. The new assays also reveal previously unknown aspects of the pathogenesis of MRSIV infections such as persistent subclinical infections undetected by histology (Study 2 and wild shovelnose sturgeon collections). That sturgeon with persistent MRSIV infections detected by PCR assays are true carriers has been demonstrated by experimental studies which resulted in virus transmission, including disease and mortality among cohabitated naïve pallid sturgeon (Kurobe et al. in press). The persistent phase may represent the major part of the virus life cycle for MRSIV, an assumption that is consistent with the observation of viral DNA in the absence of histological signs in healthy wild shovelnose sturgeon. If wild shovelnose sturgeon are indeed a major reservoir for MRSIV in the Missouri River, they represent an ongoing source for infections among MRSIV-free juvenile pallid sturgeon of hatchery origin introduced to the river for restoration efforts.

Lastly, the new PCR assays provide information critical to management strategies for reducing the negative disease impacts of hatchery-reared fish utilized for supplementation or restoration of existing wild/feral fish populations. Screening pallid sturgeon throughout their hatchery rearing and prior to their introduction to 
the river can assure managers that MRSIV is either not present or at levels (prevalence and concentrations of virus) below that found in existing wild populations. Such information allows managers to make informed decisions on supplementation with fish of hatchery origin to reduce any negative disease impacts on wild Missouri River sturgeon populations.

Acknowledgements. The authors thank Breanna Baker for conducting the TaqMan PCR and Kenneth Staigmiller, Montana Fish Wildlife and Parks, for collection of the wild shovelnose sturgeon. This research was supported in part by the Army Corps of Engineers. We also thank Jim Winton and Bill Batts at the Western Fisheries Research Center, Seattle, Washington, USA, for conducting PCR tests on split samples between laboratories.

\section{LITERATURE CITED}

Adkison MA, Cambre M, Hedrick RP (1998) Identification of an iridovirus in Russian sturgeon (Acipenser guldenstadi) from northern Europe. Bull Eur Assoc Fish Pathol 18: 29-32

Bemis WE, Kynard B (1997) Sturgeon rivers: an introduction to acipenseriform biogeography and life history. Environ Biol Fishes 48:167-183

Bercovier H, Fishman Y, Nahary R, Sinai S and others (2005) Cloning of the koi herpesvirus (KHV) gene encoding thymidine kinase and it use for a highly sensitive PCR based diagnosis. BMC Microbial 5:13-21

Birstein VJ (1993) Sturgeons and paddlefishes: threatened fishes in need of conservation. Conserv Biol 7:773-787

Boyle J, Blackwell J (1991) Use of polymerase chain reaction to detect latent channel catfish virus. Am J Vet Res 52: 1965-1968

Braaten PJ, Fuller DB, Lott RD, Jordan GR (2009) An estimate of the historic population size of adult pallid sturgeon in the upper Missouri River Basin, Montana and North Dakota. J Appl Ichthyology 25:2-7

Cohen J (1960) A coefficient of agreement for nominal scales. Educ Psychol Meas 20:37-46

> Drennan JD, Ireland S, LaPatra SE, Grabowski L, Carrothers TK, Cain KD (2005) High-density rearing of white sturgeon (Acipenser transmontanus) induces white sturgeon iridovirus disease. Aquat Res 36:824-827

> Drennan JD, LaPatra SE, Siple JT, Ireland S, Cain KD (2006) Transmission of white sturgeon iridovirus in Kootenai River white sturgeon Acipenser transmontanus. Dis Aquat Org 70:37-45

Duffy W, Berry C, Keenlye K (1996) The pallid sturgeon: biology and annotated bibliography through 1994. Technical bulletin No. 5. South Dakota Cooperative Fish and Wildlife research unit, South Dakota State University, Brookings, SD

Georgiadis MP, Hedrick RP, Johnson WO, Yunn S, Gardner IA (2000) Risk factors for outbreaks of disease attributable to white sturgeon iridovirus and white sturgeon herpesvirus- 2 at a commercial sturgeon farm. Am J Vet Res 61:1232-1240

> Georgiadis MP, Hedrick RP, Carpenter TE, Gardner IA (2001) Factors influencing the transmission, onset, and severity of outbreaks of white sturgeon iridovirus (WSIV) in a commercial hatchery. Aquaculture 194:21-35
Gilad O, Yun S, Andree KB, Adkison MA and others (2002) Initial characteristics of koi herpesvirus and development of a polymerase chain reaction assay to detect the virus in koi, Cyprinus carpio. Dis Aquat Org 48:101-108

- Gilad O, Yun S, Zagmutt-Vergara FJ, Leutenegger CM, Bercovier H, Hedrick RP (2004) Concentrations of a Koi herpesvirus (KHV) in tissues of experimentally-infected Cyprinus carpio koi as assessed by real-time TaqMan PCR. Dis Aquat Org 60:179-187

Goodwin AE, Merry GE, Sadler J (2006) Detection of the herpesviral hematopoietic necrosis disease agent (Cyprinid herpesvirus 2) in moribund and healthy goldfish: validation of a quantitative PCR diagnostic method. Dis Aquat Org 69:137-143

> Gray WL, Williams RJ, Jordan RL, Griffin BR (1999) Detection of channel catfish virus DNA in latently infected catfish. J Gen Virol 80:1817-1822

> Guerin JL, Gelfi J, Camus C, Delverdier M and others (2001) Characterization and functional analysis of Serp3: a novel myxoma virus-encoded serpin involved in virulence. J Gen Virol 82:1407-1417

> Hedrick RP, Groff JM, McDowell TS, Wingfield WH (1990) An iridovirus infection of the integument of the white sturgeon Acipenser transmontanus. Dis Aquat Org 8:39-44

> Hedrick RP, McDowell TS, Rosemark R, Aronstein D, Lannan CN (1991) Two cell lines from white sturgeon (Acipenser transmontanus). Trans Am Fish Soc 120:528-534

Hedrick RP, McDowell TS, Groff JM, Yun S, Wingfield WH (1992) Isolation and some properties of an iridovirus-like agent from white sturgeon Acipenser transmontanus. Dis Aquat Org 12:75-81

Humason GL (1979) Animal tissue techniques, 4th edn. Freeman, San Francisco, CA

Kapuscinski K (2002) Population abundance estimation of wild pallid sturgeon in recovery-priority management area \#2 of the Missouri and Yellowstone Rivers during 1991-2001 in 2002 upper basin pallid sturgeon work group annual report. Montana Department of Fish, Wildlife and Parks, Fort Peck, MT

Knopf CW (1998) Evolution of viral DNA-dependent DNA polymerases. Virus Genes 16:47-58

Kurobe T, Kelley GO, Waltzek TB, Hedrick RP (2008) Revised phylogenetic relationships among herpesviruses isolated from sturgeons. J Aquat Anim Health 20:96-102

Kurobe T, Marcquenski S, Hedrick RP (2009) PCR assay for improved diagnostics of epitheliotropic disease virus (EEDV) in lake trout Salvelinus namaycush. Dis Aquat Org 84:17-24

Kurobe T, MacConnell E, Hudson C, McDowell TS, Mardones FO, Hedrick RP (in press) Iridovirus infections among pallid and shovelnose sturgeon: initial characterization, transmission and evidence for establishment of a carrier state. J Aquat Anim Health

> Kwak KT, Gardner IA, Farver TB, Hedrick RP (2006) Rapid detection of white sturgeon iridovirus (WSIV) using a polymerase chain reaction (PCR) assay. Aquaculture 254: 92-101

> LaPatra SE, Groff JM, Jones GR, Munn B and others (1994) Occurrence of white sturgeon iridovirus infections among cultured white sturgeon in the Pacific Northwest. Aquaculture 126:201-210

LaPatra SE, Groff JM, Patterson TL, Shewmaker WD, Casten M, Siple J, Hauck AK (1996) Preliminary evidence of sturgeon density and other stressor on manifestation of white sturgeon iridovirus disease. J Appl Aquacult 24:6-13

Law RH, Zhang Q, McGowan S, Buckle AM and others (2006) An overview of the serpin superfamily. Genome Biol 7: $216-227$ 
Ludwig A, Belfiore NM, Pitra C, Svirsky V, Jenneckens I (2001) Genome duplication events and functional reduction of ploidy levels in sturgeon (Acipenser, Huso and Scaphirhynchus). Genetics 158:1203-1215

Raverty S, Hedrick RP, Justine H, Saksida S (2003) Diagnosis of sturgeon iridovirus infection in farmed white sturgeon in British Columbia. Can Vet J 44:327-328

Rodgers JL, Nicewander WA (1988) Thirteen ways to look at the correlation coefficient. Am Stat 42:59-66

Song WJ, Qin QW, Qiu J, Huang CH, Wang F, Hew CL (2004) Functional genomics analysis of Singapore grouper iridovirus: complete sequence determination and proteomic analysis. J Virol 78:12576-12590

Thompson JD, Higgins DG, Gibson TJ (1994) Clustal W:

Editorial responsibility: V. Gregory Chinchar,

Jackson, Mississippi, USA improving the sensitivity of progressive multiple sequence alignment through sequence weighting, position specific gap penalties and weight matrix choice. Nucleic Acids Res 22:4673-4680

Viera AJ, Garrett JM (2005) Understanding interobserver agreement: the kappa statistic. Fam Med 37:360-363

Waltzek TB, Kurobe T, Goodwin AE, Hedrick RP (2009) Development of a polymerase chain reaction assay to detect cyprinid herpesvirus 2 in goldfish. J Aquat Anim Health 21:60-67

Watson LR, Groff JM, Hedrick RP (1998) Replication and pathogenesis of white sturgeon iridovirus (WSIV) in experimentally infected white sturgeon Acipenser transmontanus juveniles and sturgeon cell lines. Dis Aquat Org 32:173-184

Submitted: January 28, 2010; Accepted: September 8, 2010 Proofs received from author(s): November 8, 2010 